\title{
AN UNSETTLED ISSUE IN VERTICAL FISCAL ADJUSTMENT IN NIGERIA: THE NON-CORRESPONDENCE PROBLEM
}

\author{
Gini Mbanefoh
}

\section{Introduction}

The Nigerian federal system, as presently constituted, contemplates a division of governmental sovereignty among three levels of government - federal, state and local. Consequent upon the division of governmental sovereignty among the three tiers of government is the allocation of functions and revenue-sharing powers among them.

Ideally, each level of government should be given adequate financial resources to enable it to discharge the duties and responsibilities assigned to it. This is essential for the preservation of the autonomy of the constituent units. In practice, however, it is virtually impossible in a federation to adjust the functions of the constituent units to their financial resources. A member may have more financial power than it actually needs, and another less. Consequently, there is usually a lack of correspondence between the functions assigned to the various levels of government and the tax powers/revenue sources assigned to them. This incongruence between spending responsibilities and revenue resources is generally referred to as the non-correspondence problem (NCP).

Though the non-correspondence problem is not new in Nigerian fiscal federalism, the shifts in fiscal responsibilities from the federal to other levels of government, especially the local governments, as the country marches towards the Third Republic, has once more brought the problem to the forefront This paper reviews the non-correspond- 


\section{Annals of the Social Council of Nigeria}

ence problem in Nigeria and examines a number of approaches to the solution of the problem.

The second part of the paper is devoted to a discussion of issues on the allocation of functions and tax powers in a federal set-up. The constitutional allocation of functions and tax powers is taken up in section three. Some evidence of the magnitude of fiscal imbalance in respect of the various tiers of government is presented in section four, while some approaches to the solution of the non-correspondence problem are taken up in section five. Section six is the concluding part of the paper.

\section{Issues in The Allocation of Fiscal Responsibilities}

\section{ALLOCATION OF FUNCTIONS}

If political authority is divided among levels of government, the first problem, as noted earlier, is that of determining the appropriate public functions to be performed by each level. Two factors may influence the allocation of functions among the different levels of government. One is the geographic range of spillover effects or benefits of collective actions; the other is economies of scale.

Ideally, the economic or efficient division of responsibility should depend on the geographic range of spillover effects or benefits from governmental action (Buchanan 1970). In other words, each function should be assigned to that level of government that coincides in size with the group that benefits from the activity. This implies that the national or the central government would provide those public services that benefit the whole national population, while state and local governments would provide those services whose benefits are more divisible geographically. Put differently, functions which are more local than national should be assigned to lower level governments, while those which are more national than local should be assigned to the national government.

Another reason why federating units may decide to federate could be to take advantage of economies of scale. Certain functions can be performed more efficiently (in terms of lower unit cost) by the national government than by lower level governments.

\footnotetext{
ALLOCATION OF TAX POWERS

As in the case of function allocation, some factors also influence the assignment of tax jurisdiction among the different tiers of government. These are mostly administrative efficiency and fiscal independence. The efficiency criterion demands that $\&$ tax be assigned to that level of government that will administer it efficiently at minimum cost. Fiscal independence requires that each level of government
} 
should, as far as possible, raise adequate resources from the revenue sources assigned to it, to meet its needs and responsibilities.

Very often the efficiency criterion tends to be in conflict with the principle of Fiscal independence; for, while the former calls for a great deal of concentration of tax powers at the higher levels of government, due to the limited administrative capacity of subordinate units, the latter demands the devolution of more tax power to lower units of government to match the functions assigned to them. In the Nigerian context, the weighting has always been tilted in favour of the efficiency criterion.

\section{Disposition of Functions and Tax Powers \\ in Nigerian Federation DISPOSITION OF FUNCTIONS}

The present disposition of functions among the units in the Nigerian federal system is as contained in the Constitution of the Federal Republic of Nigeria (promulgation) Decree 1989 (hereafter referred to as the New Constitution.) Section 4 of the New Constitution specifies three categories of legislative powers, namely: the Exclusive Legislative List, on which only the Federal government can act; the Concurrent Legislative List on which both the Federal and the State governments can act; and the socalled residual functions consisting of any matter not included in the Exclusive Legislative List on which the States can act. Section 7 of the New Constitution makes provision for the establishment of local governments whose functions are specified in its Fourth Schedule. It is important to point out that the allocation of functions in the New Constitution is not very different from that of the 1979 Constitution (which was being replaced), or even in the earlier ones.

While the allocation of functions among federating units is more of a political than an economic exercise, and while there may be no stated principles underlying such allocation, it is not unreasonable to infer that considerations of the extent of the benefitregion of governmental services and economies of scale must have weighed heavily in the decision to allocate some functions to the Federal government and others to the lower levels of government. Hence, those functions whose benefit-region covers the entire country or which can be more efficiently performed by the Federal government have been assigned to it. These include national defence, external relationships (including borrowing and external trade), banking, currency, coinage and legal tender, weights and measures, nuclear energy, etc.

Functions whose benefit-areas are more local than national but with the possibility of spill-over effects have been placed in the Concurrent Legislative List. Such functions relate to antiquities and 


\section{Annals of the Social Council of Nigeria}

archives; electric power; industrial, commercial or agricultural development; scientific and technological research; universities as well as technological and post-primary institutions.

Finally, functions which are purely local in character, in the sense that the benefits accrue, in the main, to limited geographic areas within the country, are usually assigned to local authorities. Such functions would include the establishment and maintenance of cemeteries; markets, motor parks and public conveniences; refuse disposal; as well as the construction and maintenance of local roads and streets. For instance, the consequences of non-disposal of refuse in a particular locality will be mostly internalised by the residents of that locality.

\section{ALLOCATION OF TAX POWERS}

A proper understanding of the basis of the allocation of tax powers in the Nigerian federal system requires a brief review of the evolution of the division of tax powers. Between 1914 and 1951, Nigeria operated a unitary system of government, in which the central government weilded much power in fiscal matters. However, the creation of regional authorities in 1946 called for some formalisation of the fiscal relationship between the central and the regional authorities. Thus, the 1947 Constitution identified two sources of revenue for the regional authorities. One was "declared revenue" and the other was "non-declared revenue". The former represented revenue which the regional authorities were expected to raise within their areas of jurisdiction, while the latter consisted of block grant from the central revenues to the regional authorities (Okigbo 1965: 10 and Adedeji 1969:50).

Given the above framework for the division of tax powers between the central and the regional authorities, a number of issues had to be resolved, two of which are of interest to us here. One was the criterion for declaring a revenue source as regional, and the other, the basis for determining the size of the block grants from central revenue.

In Nigeria, the task of fashioning out the details of the fiscal relationships to accompany constitutional changes has always been entrusted to fiscal commissions of which the country had nine to date. The first of these - the Philipson's Commission appointed in 1946, set very strigent conditions for declaring any revenue source as regional. For instance, regional revenues (Okigbo 1965:16):

(i) were to be essentially local in character for easy assessment and allocation;

(ii) would have to be regionally identifiable; and (iii) would have no implications for national policy. 
Given the conditions above, it became obvious that very few revenue sources (taxes) would qualify as regional revenue. Thus, even where it was genuinely felt that the regions deserved to have jurisdiction over certain taxes based on their revenue needs, and the fact that taxes were local in character and regionally identifiable, considerations of national interest (such as free movement of people, goods and resources across regional boundaries or fiscal management of the economy) might make it imperative that jurisdiction over such taxes be not bestowed on the regional /state authorities. ${ }^{4}$

It follows that whatever revenue sources that eventually passed the acid test and qualified as regional revenues would be grossly inadequate to give the regions a reasonable measure of fiscal autonomy in the performance of the functions assigned to them. This is the origin of the non-correspondence problem (NCP). Perhaps, it would be instructive to point out that, while the principle of maximum independent revenues (as the declared revenues later came to be known) for the regions (now states) and, subsequently, local governments, was generally accepted by all the subsequent commissions, they all share the same pessimism as far as the achievement of that objective is concerned, noting that the scope for the enlargement of tax jurisdiction of lower level governments was disappointingly small.

The actual disposition of revenue jurisdiction in Nigeria from $1970-1989$ is shown in Table 1. Because of the limited scope for manoeuvrability already noted, there have been very few changes with respect to the allocation of tax jurisdiction. The only notable exceptions were the transfer of the legal aspects of capital gains tax, personal income tax and sales tax from the State governments to the Federal government, as it became obvious that these taxes did not fully satisfy the conditions required to have them declared as truly state taxes.

Table 1 clearly indicates that all the major sources of revenue - import duties, excise duties, petroleum profit tax, mining rents and royalties, and companies' income tax - come under the jurisdiction of the Federal government. The implications of localising these revenue sources for the overall fiscal management of the economy, unimpeded movement of people and resources across state and local government boundaries, maintenance of external balance, and efficiency in tax administration, are rather obvious. Thus, with the exception of personal income tax and sales tax (at the state level) and property taxation (at the local government level) whose potentials are yet to be fully tapped, the and States Local 
Table 1

MAJOR REVENUE JURISDICTION IN NIGERIA, 1970-1989

\begin{tabular}{|c|c|c|c|}
\hline$S / N$ & Source of Revenue & Jurisdiction & Right to Revenue \\
\hline 1. & Import Duties & Federation & $\begin{array}{l}\text { Federation } \\
\text { Account }\end{array}$ \\
\hline 2. & Excise Duties & Federation & Federation Account \\
\hline 3. & Export Duties & Federation & Federation Account \\
\hline 4. & $\begin{array}{l}\text { Mining Rents and } \\
\text { Royalties }\end{array}$ & Federation & Federation Account \\
\hline 5. & $\begin{array}{l}\text { Petroleum Profit } \\
\text { Tax }\end{array}$ & Federation & $\begin{array}{l}\text { Federation } \\
2 \text { Account }\end{array}$ \\
\hline 6. & $\begin{array}{l}\text { Companies Income } \\
\text { Tax }\end{array}$ & Federation & $\begin{array}{l}\text { Federation } \\
\text { Account }\end{array}$ \\
\hline 7. & Capital Gains Tax & $\begin{array}{l}\text { Federation } \\
\text { (legal) States } \\
(\text { Adm.) }\end{array}$ & States \\
\hline 8. & $\begin{array}{l}\text { Personal Income } \\
\text { Tax }\end{array}$ & $\begin{array}{l}\text { Federation } \\
(\text { legal })^{3} \text { States } \\
(\text { Adm. })\end{array}$ & States \\
\hline 9. & $\begin{array}{l}\text { Licence Fees/ TV } \\
\text { Wireless Radio }\end{array}$ & Federation & Federation \\
\hline 10. & Stamp Duties & $\begin{array}{l}\text { Federation } \\
(\text { legal })^{3} \text { States } \\
(\text { Adm. })\end{array}$ & States \\
\hline 11. & Estate Duties & $\begin{array}{l}\text { Federation } \\
\text { (legal) States } \\
\text { (Adm.) }\end{array}$ & States \\
\hline 12. & Gift Tax & $\begin{array}{l}\text { Federation } \\
(\text { legal })^{3} \text { States } \\
(\text { Adm. })\end{array}$ & States \\
\hline 13. & Sales / Purchase Tax & $\begin{array}{l}\text { Federation } \\
(\text { legal })^{3} \text { States } \\
(\text { Adm. })\end{array}$ & States \\
\hline 14. & $\begin{array}{l}\text { Motor Vehicle Tax } \\
\& \text { Drivers Licence } \\
\text { Fees }\end{array}$ & States & States \\
\hline $\begin{array}{l}15 . \\
16 .\end{array}$ & $\begin{array}{l}\text { Entertainment Tax } \\
\text { Property Tax }\end{array}$ & $\begin{array}{l}\text { States } \\
\text { States (legal) }\end{array}$ & $\begin{array}{l}\text { States } \\
\text { Local Governments }\end{array}$ \\
\hline 17. & $\begin{array}{l}\text { Land Registration } \\
\& \text { Survey Fees }\end{array}$ & $\begin{array}{l}\text { Local Govts } \\
\text { (Adm.) } \\
\text { States }\end{array}$ & $\begin{array}{l}\text { States /Local } \\
\text { Governments. }\end{array}$ \\
\hline
\end{tabular}


An Unsettled Issue in Vertical Fiscal Adjustment $\mathbf{3 7}$

\begin{tabular}{|l|l|l|l|} 
SIN & Source of Revenue & Jurisdiction & Right to Revenue \\
\hline 18. & $\begin{array}{l}\text { Football Pools \& } \\
\text { Other Betting Taxes } \\
\text { Market \& Trading } \\
\text { 19. }\end{array}$ & States & States/L. Govts \\
Licence Fees \\
20. & $\begin{array}{l}\text { Motor Park Dues } \\
\text { Land Ground Rent } \\
\text { Fees }\end{array}$ & $\begin{array}{l}\text { States /L.Govts } \\
\text { States/LGovts }\end{array}$ & $\begin{array}{l}\text { L/Govts } \\
\text { States/L.Govts }\end{array}$ \\
\hline
\end{tabular}

1. The Federation Account is an account into which all federally collected revenues is paid, to be shared among the three tiers of government.

2. by Decrees No. 13 of 1970, the Federal government originally had exclusive right to revenue from these sources.

3. The Federal government administers and retains the revenue from personal income tax on the residents of the Federal territory, according to the 1989 Constitution.

4. With the promulgated Sales Tax Decree, the Federal government has assumed jurisdiction for Sales Tax throughout the country.

Source: Compiled from The 1963 Constitution, The 1979 Constitution and The 1989 Constitution.

Governments have jurisdiction over minor and poor-yielding revenue sources, such as football pools and other betting taxes, entertainment tax, motor vehicle and drivers licences fees, land ground rent, market and trading licences and fees as well as motor park dues.

Table 2 shows the proportion of the combined revenues of the Federal and State governments collected by each. State governments' independent revenue as a proportion of the total recurrent revenue of the Federal and State governments averaged 6.6\% between 1970 and 1989.

\section{Further Evidence of the Non-Correspondence Problem}

Some indications of the existence and magnitude of the NCP are presented in Tables 3 and 4 with respect to State and Local governments respectively. Table 3 shows that the State governments have been generating, on the average, only about $21.5 \%$ of their total current revenue from internal sources, implying a heavy dependence on the Federal government as a major source of funding. It also shows 
Table 2

RELATIVE CONTRIBUTIONS OF FEDERAL AND STATE GOVERNMENTS TO TOTAL, CURRENT REVENUE

\begin{tabular}{|l|l|l|l|l|l|}
\hline Year & $\begin{array}{l}\text { Total } \\
\text { Current } \\
\text { Revenue }\end{array}$ & \multicolumn{3}{|l|}{$\begin{array}{l}\text { Federally } \text { Collected } \\
\text { Revenue }\end{array}$} & \multicolumn{2}{|l|}{$\begin{array}{l}\text { State Independent } \\
\text { Revenue }\end{array}$} \\
\cline { 2 - 6 } & $\mathrm{Nm}$ & $\mathrm{Nm}$ & $(\%)$ & $\mathrm{Nm}$ & $(\%)$ \\
\hline 1970 & 702.2 & 634.1 & $(90.3)$ & 68.1 & $(9.7)$ \\
1972 & $1,524.7$ & $1,404.8$ & $(92.1)$ & 119.9 & $(7.9)$ \\
1974 & $4,735.0$ & $4,537.5$ & $(95.8)$ & 197.5 & $(4.2)$ \\
1976 & $7,059.2$ & $6,766.0$ & $(95.8)$ & 293.2 & $(4.2)$ \\
1978 & $7,682.0$ & $7,469.4$ & $(97.2)$ & 212.6 & $(2.8)$ \\
1980 & $16,561.7$ & $15,234.0$ & $(92.0)$ & $1,327.7$ & $(8.6)$ \\
1982 & $13,080.2$ & $11,764.4$ & $(89.9)$ & $1,315.8$ & $(10.1)$ \\
1984 & $13,148.1$ & $11,766.8$ & $(89.5)$ & $1,318.3$ & $(10.5)$ \\
1986 & $14,698.2$ & $12,837.6$ & $(87.3)$ & $1,860.6$ & $(12.7)$ \\
1988 & $29,489.6$ & $27,310.8$ & $(92.6)$ & $2,178.8$ & $(7.4)$ \\
1989 & $51,874.3$ & $50,272.0$ & $(96.9)$ & $1,602.3$ & $(31)$ \\
& & & & & \\
\hline
\end{tabular}

Provisional figures.

Sources: Central Bank of Nigeria-

1. Annual Report and Statement of Accounts (various issues)

2. Economic and Financial Review (various issues) 
Table 3

STATE GOVERNMENTS FISCAL POSITION, 1970-1989

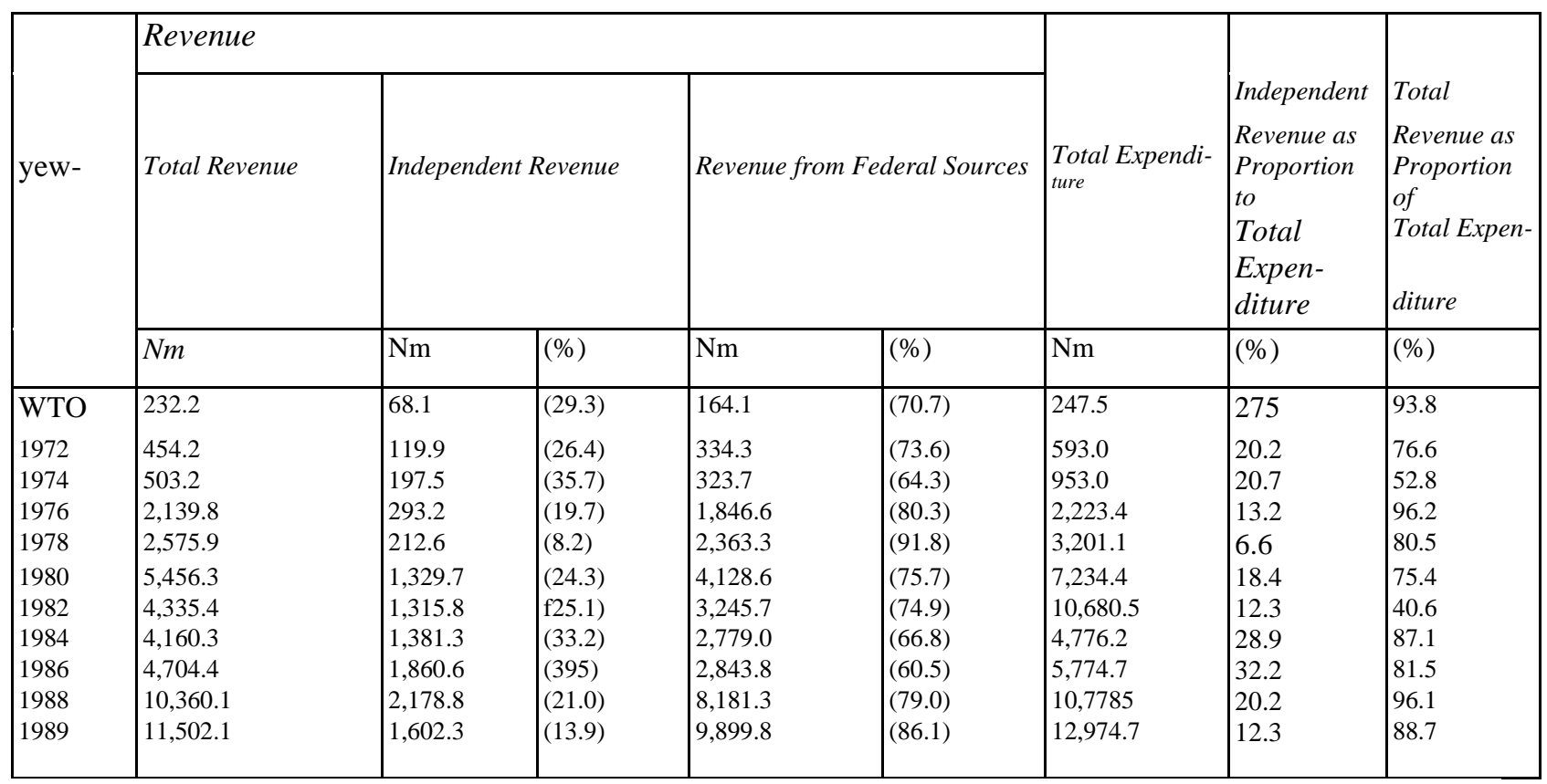

Provisional figures.

Sources: Central Bank of Nigeria -

1. Annual Report and Statement of Accounts (various issues)

2. Economic and Financial Review (various issues) 
38 Annals of the Social Council of Nigeria

Table 4

FISCAL POSITIONS OF SELECTED LOCAL GOVERNMENTS, 1986

\begin{tabular}{|c|c|c|c|c|c|c|c|}
\hline \multirow[t]{3}{*}{ Local Government } & \multicolumn{5}{|c|}{ Revenue } & \multirow{3}{*}{\begin{tabular}{|l}
$\begin{array}{l}\text { Total Expen- } \\
\text { diture }\end{array}$ \\
\\
$\mathrm{Nm}$
\end{tabular}} & \multirow{3}{*}{\begin{tabular}{|l} 
intemalfyGen \\
-crated \\
Revenue \\
as\%of Total \\
Expenditure \\
\\
$(\%)$
\end{tabular}} \\
\hline & \multirow{2}{*}{\begin{tabular}{|l} 
Total \\
$\mathrm{Nm}$
\end{tabular}} & \multicolumn{2}{|c|}{ Internally Generated } & \multicolumn{2}{|c|}{ External Sources } & & \\
\hline & & $\mathrm{Nm}$ & $(\%)$ & $\mathrm{Nm}$ & $(\%)$ & & \\
\hline Abeokuta Local Govt (Ogun State) & 4.938 & 2.153 & $(43.6)$ & 2.785 & $(56.4)$ & 13.918 & 155 \\
\hline Odeda Local Govt (Ogun State) & 2556 & 0552 & (21.6) & 2.004 & (78.4) & 2.074 & 26.6 \\
\hline Okpebho Local Govt (Bendel State) & 3.314 & 0.327 & 99.9) & 2.987 & (90.1) & 3.417 & 9.6 \\
\hline Etsako local Govt (Bendel State) & 3.572 & 0.209 & $(5.9)$ & 3.363 & $(94.1)$ & 3.858 & 5.4 \\
\hline Gboko Local Govt (Niger State) & 2.451 & 0.448 & $(I S .3 Y$ & 2.003 & $(81.7)$ & 2363 & 175 \\
\hline Mariga Local Govt (Niger State) & 1.291 & 0.323 & $(25.0)$ & 0.968 & $(75.0)$ & 1.685 & 19.2 \\
\hline
\end{tabular}

Mostly from Federal Government sources.

Source: Survey Data from Bello-Imam (ed): Local Government Finance in Nigeria, Ibadan, NISER, 1990. 
that, on the average, only about $19.3 \%$ of the total expenditure of the State governments could be financed out of their independent revenue sources, thus showing a wide gap between their expenditure needs and the revenue derived from the revenue sources assigned to them.

The Local governments portray the same pattern of heavy dependence on external sources of funding (about $80.0 \%$ on the average) and the existence of a wide gap between their internally generated revenue and their expenditure needs. (Refer to Table 4). On the average, the internally generated revenue of the sampled local governments could only finance about $15.6 \%$ of their total expenditure.

\section{Approaches to resolving the Non-Correspondence Problem}

The imbalance between the functions assigned to the different tiers of government (especially state and local governments) and the sources of revenue assigned to them, to enable them to perform those functions, can be tackled in a number of ways. These include: shifting functions from revenue deficit units to surplus units; re-alignment of tax jurisdiction in favour of revenue deficit units; transfer of financial resources from surplus to deficit units; attempts to generate more internal revenue by deficit units; borrowing by deficit units and expenditure reduction.

\section{RE-ALIGNMENT OF FUNCTIONS AND TAX POWERS}

From the earlier analysis, it appears that the Federal government could be regarded as the surplus unit, given the paltriness of the taxes assigned to the state and local governments when compared to their revenue needs. It was also pointed out that it is virtually impossible in a federation to nicely adjust the functions entrusted to the members to their financial resources. Besides, usually different principles guide the assignment of functions and tax powers in a federal system. While geographic range of benefits and scale economies weigh heavily in the allocation of functions, administrative capability rather than fiscal independence, is given the pride of place in the assignment of tax powers.

It would, therefore, appear that not much could be achieved by any major tinkering with the present allocation of functions and tax powers in the Nigerian federal system. Re-assigning functions to match revenue resources might necessitate assigning to the Federal government functions that would otherwise be more suitable for lower levelgovernments. This will only reinforce the concentration of functions on the Federal government contrary to the spirit of a 


\section{Annals of the Social Council of Nigeria}

decentralised fiscal system. On the other hand, re-assigning tax powers to match functions might entail transferring to lower level governments tax sources that they may not be able to administer efficiently. One might, indeed, speculate that the relative stability of the allocation of functions and tax powers under the Nigerian federal finance might have been informed by the fact that not much headway would be made in the direction of re-assignment of functions and tax powers.

There have, of course, been some attempts to solve the non-correspondence problem by shifting functions from one level of government to another. As a result of its access to the more elastic sources of revenue in the 1970s; the Federal Military Government caused some functions to be shifted from the state and local governments to the central authority. These included: university and primary education to some extent, television and radio broadcasting, and major newspapers. This led to the accusation that the Federal government was doing too much of things it should not do and too little of things it ought to do. It was only during the Second Republic (1979 - 83) that the civilian state governments fought back and regained control over some of their functions formerly usurped by the Federal government (Mbanefoh 1986a).

The only other attempts to make adjustments in the allocation of fiscal responsibilities and tax powers among the units in the Nigerian federation was that of the Aboyade Technical Committee on Revenue Allocation. But, despite the Committee's conviction that fiscal independence is the true foundation for fiscal responsibility in a federal system of government, it was quick to admit that in the Nigerian context, the proportional contribution of independent revenue sources as the state and local levels would continue to be minimal for sometime.

Right now, the present military administration is transferring some functions, notably education and primary health care to where they really belong - the local governments. Desirable as this move is, it can exacerbate the non-correspondence problem unless the financial implications are carefully worked out and adequately taken care of.

\section{FINANCIAL TRANSFERS}

Given the difficulty of matching functions with tax powers, it would appear that a more realistic approach to the problem is through some financial transfers from the surplus to the deficit units. Here, one can think of two types of transfers. The first is the transfer necessitated by the fact that, due to tax advantage constitutionally conferred on the Federal government, central-government revenue is being substituted 
for lower level revenue. Hence, access of the lower level government to such revenue is through some formal revenue sharing arrangement. The other is necessitated by the central government's desire to collect for spill-over of benefits (or externalities), or to maintain minimum standards of certain services across the nation. This transfer generally takes the form of grants.

With respect to revenue sharing, a distinction has to be made between sharing among the different tiers of government (vertical sharing) and that among units within a given level of government (horizontal sharing). The interest here is in the former. Perhaps, it is important to point out that the earlier practice with respect to vertical sharing was to assign specific proportions of the revenues from specific sources to the Federal and State governments. The Aboyade Committee recommended that all federally-collected revenues, with minor exceptions, should be paid into the Federation Account and shared among the three tiers of government in pre-determined proportions. This aspect of the Committee's report was accepted and incorporated into the 1979 Constitution. One implication of this recommendation is that it brought the states and local governments into the sharing of revenues from the most lucrative sources. It also brought the local governments formerly into the vertical sharing arrangement for the first time. ${ }^{\wedge}$ The earlier practice may explain why, in spite of her having to share the federallycollected revenues with the state governments, the Federal government still retained the lion's share of such revenues prior to the Second Republic (1979-83) and the creation of the Federation Account, as shown in Table 5.

The current revenue-sharing arrangement, as compared with the preceding one, is presented in Table 6 . The only significant change is the 5\% increase in the allocation to the local governments at the expense of the Federal government. Reference has earlier been made to the devolution of more responsibilities to the local governments by the Federal government. Also, as against their advisory role (to the State governments), the 1979 Constitution and the New Constitution the Federal government charged the local governments with the responsibility for the formulation of economic planning and development schemes for their areas, in apparent recognition of the importance of grassroots development. It should, perhaps, be pointed out here that, in spite of the increase in the allocation to local governments, their share of the Federation Account still falls short of the $20 \%$ recommendation by the Political Bureau, and there are widespread doubts as to the ability of the local 
44 Annals of the Social Council of Nigeria

Table 5

PROPORTION OF REDERALLY COLLECTED REVENUE RETAINED BY THE FEDERAL GOVERNMENT (1970 - 1990)

\begin{tabular}{|l|l|l|l|}
\hline \multirow{2}{*}{ Year } & $\begin{array}{l}\text { Total Federally } \\
\text { Collected Revenue }\end{array}$ & \multicolumn{2}{|l|}{$\mid \begin{array}{l}\text { Federal } \\
\text { Retained Revenue }\end{array}$} \\
\cline { 2 - 4 } & $\mathrm{Nm}$ & $\mathrm{Nm}$ & $(\%)$ \\
\hline 1970 & 634.1 & 543.1 & $(85.7)$ \\
1972 & $-1,404.8$ & $1,073.8$ & $(76.4)$ \\
1974 & $4,537.5$ & $3,894.0$ & $(85.8)$ \\
1976 & $6,766.0$ & $5,623.1$ & $(83.1)$ \\
1978 & $7,469.4$ & $5,028.1$ & $(67.3)$ \\
1980 & $15,234.0$ & $9,040.0$ & $(59.3)$ \\
1982 & $11,764.4$ & $7,500.0$ & $(63.8)$ \\
1984 & $11,766.8$ & $6,234.1$ & $(53.0)$ \\
1986 & $12,837.6$ & $8,505.0$ & $(66.3)$ \\
1988 & $27,318.0$ & $15,588.6$ & $(57.1)$ \\
1990 & $47,657.0$ & $25,431.0$ & $(53.4)$ \\
\hline
\end{tabular}

Budget estimates.

Sources: $\quad$ Central Bank of Nigeria -

1. Annual Report and Statement of Accounts (various issues)

2. Economic and Financial Review (various issues). 
Table 6

CURRENT VERTICAL REVENUE SHARING ARRANGEMENT COMPARED WITH THE PRECEDING ONE

\begin{tabular}{|l|l|l|}
\hline & $\begin{array}{l}\text { Preceding Formula } \\
(\%)\end{array}$ & $\begin{array}{l}\text { Current } \\
(\%)\end{array}$ \\
\hline Federal Government & 55.0 & 50.0 \\
State Government & 30.5 & 30.0 \\
Local Government & 10.0 & 15.0 \\
Special Fund & $4.5^{3}$ & $5.0^{4}$ \\
\hline
\end{tabular}

1. Arising from the Okigbo Commission's Report

2. Arising from the National Revenue Mobilisation, Allocation and Fiscal Commission Report

3. $\%$ for tackling ecological problems, and 3.5\% (of mineral revenues) for the mineral-producing areas.

4. Includes funds for ecological problems, for oil- producing areas and for stabilisation.

governments to shoulder the financial burden of their added responsibilities.

Finally, one would like to add that revenue-sharing on the basis of functions is complicated by the fact that the mere listing of such functions does not take into account the quantitative and qualitative dimensions. In other words, the allocation of functions to different levels of government does not necessarily connote an ordering of such functions, nor is it indicative of their relative importance, at least, from the point of view of the majority of the people for whom the services are provided. In the final analysis, the weighting of the functions must be coloured by the prevailing socio-economic and political philosophy of the society. While militarism, going by the recent experience of the Gulf War, might regard the entire federal budget as in adequate for defence purposes, there is no limit to the premium that welfarism would place on education, health and shelter for the people. 


\section{Annals of the Social Council of Nigeria}

\section{INCREASE IN INTERNALLY-GENERATED REVENUE}

The present Structural Adjustment Programme (SAP) lays emphasis on the need for state and local governments to increase their internal revenues above the existing levels through a combination of improvement in efficiency in revenue collection from already existing revenue sources, increase in the rate of existing taxes and broadening of revenue base by introducing new forms of taxation. Ail indications are that these levels of government are yet to establish efficient revenue collection machinery. It has also been pointed out that the rates of potential revenue taxes and charges are very low. However, the potential revenue gain must be weighed against the possible disincentive effects of rate increases.

Finally, while the introducing of new taxes is a way of generation additional revenue, the demerits of a complicated tax system must be noted. A multiple tax system has the advantage of spreading the tax dragnet as wide as possible, whereas very complex tax structures can create collection and compliance problems, especially given the limitations on the administrative capacities of these levels of government. Hence, it may be more worthwhile to focus attention primarily on devising efficient machinery for revenue collection from already familiar sources. It has also been argued that in a non-military era, where winning votes is not an important aspect of the objective function of the political process, increasing the rates of existing taxes or introducing new taxes has never been particularly appealing to political decision-makers (Mbanefoh, 1986b).

\section{BORROWING}

Governments with insufficient resources to back up their expenditure needs may resort to deficit financing. The lower level governments, especially the state governments, have been very notorious in their recourse to deficit financing until recently when the Federal government imposed stricter financial discipline on them. For instance, between 1981 and 1983 (that is, during the Second Republic), the state governments deficit- financed their total expenditure programmes to the tune of 59\%. And since they do not have the power to create money, it is to be assumed that much of this deficit had to be financed by borrowing.

Sometimes the borrowing is done on behalf of the state governments by the Federal government as in cases of external loans and development loan stocks. And because of their inability to repay such loans, the Federal government is sometimes forced to compulsorily deduct the repayments due from the statutory allocations to the State governments, with very serious implications for planning and budgeting at the state level. 
As against floating development loan stocks for on-lending to them, the Federal government is urging the State and local governments to patronise the domestic capital market for specific projects. The implication of asking them to go to the capital market is to ensure that their borrowing is subjected to the rules and discipline of the market; and this implies that the projects selected for capital market funding must generate substantial, direct revenue to cover loan amortization, interest payments and operating expenses.

However, given that local governments are expected to concentrate on the provision of public services of good nature-the provision of local roads, sewage disposal, public health facilities, primary education, maintenance of cemeteries etc-one does not see how these functions can be expected to pass the market test. The implication of a fullcost recovery approach in the provision of these services for the level of utilization of the services and the equity implications are obvious. Also, uncontrolled recourse to borrowing by state and local governments can have very serious implications for the macro-economic management of the economy at the national level.

\section{EXPENDITURE REDUCTION}

Perhaps, the easiest way to resolve the non-correspondence problem, at least on the surface, and one that has found great favour in the current adjustment programme, is expenditure reduction. The declining trend in state governments' expenditure as from 1984 upwards is shown in Table 7, especially if the figures for the last three years are deflated to take account of the inflationary consequences of some of the adjustment measures. The rate of fall in expenditure is more noticeable with respect to capital expenditure with its consequent effect on capital formation at the state level.

Finally, while the conventional wisdom of cutting one's coat according to one's cloth cannot be faulted, it is also important to point out that the already established levels of expenditure, in part, reflect the degree, of need and the level of demand, and, in part, represent a precommitment that could not be easily revoked without social protest and upheaval (Okigbo 1965: 25). To get the people to 'suffer' and 'smile' at the same time is a feat which only the military can perform.

\section{Conclusions}

This essay has reviewed the origin of the non- correspondence problem in the Nigerian fiscal system and has tried to give some indication of the magnitude of the problem and examined a number of approaches to the resolution of the problem. Some of the key points that emerge from these discussions could be summarised as follows: 
Table 7

TRENDS IN STATE GOVERNMENTS' EXPENDITURE

1980-1989

\begin{tabular}{|c|c|c|c|c|c|}
\hline \multirow[t]{2}{*}{ year } & \multirow{2}{*}{$\begin{array}{l}\text { Total } \\
\text { Expenditure } \\
(\mathrm{N})\end{array}$} & \multicolumn{2}{|c|}{$\begin{array}{l}\text { Recurrent } \\
\text { Expenditure }\end{array}$} & \multicolumn{2}{|c|}{$\begin{array}{l}\text { Capital } \\
\text { Expenditure }\end{array}$} \\
\hline & & $(\mathrm{N})$ & $(\%)$ & $(\mathrm{N})$ & $(\%)$ \\
\hline 1980 & $7,234.4$ & $2,917.8$ & $(40.3)$ & 316.6 & $(59.7)$ \\
\hline 1981 & $10,909.9$ & $4,611.0$ & (42. & $6, .379 .9$ & $(57.7)$ \\
\hline 1982 & $10,680.5$ & $4,733.9$ & $(44.3)$ & $5,946.6$ & $(55.7)$ \\
\hline 1983 & $11,485.5$ & $5,392.2$ & (46.9) & $6,093.3$ & $(53.1)$ \\
\hline 1984 & $4,776.2$ & 4,1 & $(86$. & 650.3 & (13.6) \\
\hline 1985 & $5,857.1$ & $4,823.1$ & $(82$. & $1,034.0$ & $(17.7)$ \\
\hline 1986 & $5,774.7$ & $5,601.0$ & $(79.7)$ & $1,173.7$ & $\mathrm{C} 20.3$ \\
\hline 1987 & $8,263.5$ & $5,721.2$ & $(69.2)$ & $2,542.3$ & $(30.8)$ \\
\hline 1988 & $10,778.5$ & $7,193.4$ & $(66.7)$ & $3,585.1$ & (33.3) \\
\hline 1989 & $12,974.7$ & $8,140.6$ & $(62.7)$ & $4,834.1$ & $(37.3)$ \\
\hline
\end{tabular}

Provisional figures.

Sources: $\quad$ Central Bank of Nigeria -

1. Annual Report and Statement of Accounts (various issues ${ }^{1}$ )

2. Economic and Financial Review (various issues). 
(1) The non-correspondence problem arises when the functions allotted to each level of government in a federal system, and the sources of revenue assigned to them to perform these functions do not correspond.

(2) The fact that different principles tend to guide the allocation of functions and the assignment of tax powers in a federal setup makes it difficult to nicely match the functions assigned to different levels of government to the tax powers assigned to them.

(3) There is, thus, not much room for re-assignment of tax powers as currently constituted as a solution to the non-correspondence problem, without running foul of the principles that informed such allocation of tax powers in the first instance.

(4) While there might be some room for shifting some functions from higher to lower level governments, the potential of such a move in exacerbating the noncorrespondence problem must be noted and adequately taken care off.

(5) One way to tackle the non-correspondence problem is to make some adjustments in the formula for sharing federally-collected revenues among the components, taking due cognisance of not only the lists of the functions assigned to each level of government, but also the respective weighting attached to them.

(6) The deficit units could also explore avenues for increasing their internallygenerated revenues, but this must be mostly in the direction of improving the machinery for revenue collection from already existing and familiar sources.

(7) While borrowing and expenditure reduction are legitimate means of correcting the non-correspondence problem, the implications of the former for macro-economic management of the economy at the national level and the welfare implications of the latter should not be overlooked.

\section{Notes}

1. The Exclusive' Legislative List and the Concurrent Legislative List are contained in Part I and Part II respectively of the Second Schedule of the Constitution.

2. Even though Section 331 of the New Constitution provides that it shall come into force on the 1st day of October, 1992, the assignment of functions was not different from what has been obtaining since independence in 1960. See, for instance, The Nigerian (Constitution) Order in Council 1960, and The Constitution of the Federation (1963, No. 20). 


\section{Annals of the Social Council of Nigeria}

3. The first of these was the Phillipson's Commission appointed in 1946, while the ninth and current one is the Revenue Mobilization, Allocation and Fiscal Commission.

4. This is, in fact, the basis for the transfer of jurisdiction (legal basis) over personal income tax and sales tax to the Federal government, even though the State governments administer and retain the revenues from such taxes.

5. See Federal Republic of Nigeria, Report of the Technical Committee on Revenue Allocation, Vol. I, Lagos, December 1977. Even though the then Federal Military Government endorsed the Report of the Committee, the then Constituent Assembly, in its wisdom, rejected it.

6. Prior to that, the local government councils came under the residual powers of the State governments, even though the Federal government was channeling grants to them, especially in the 1970s.

7. The Political Bureau advocated $40 \%$ of the Federation Account for each of the Federal and State governments and $20 \%$ for local governments. See Federal Republic of Nigeria: Report of the Political Bureau, Lagos, March 1987, p. 66. 
An Unsettled Issue in Vertical Fiscal Adjustment 51

\section{References}

Adedeji, A: Nigerian Federal Finance, New York: Hutchinson Educational, 1969.

Buchanan, J. M. :The Public Finance, Homewood, Illinois: Richard D. Irwin, Inc, 1970.

- Report of the Presidential Commission on Revenue Allocation, Vol. 1 (Main Report), Apapa: Federal Government Press, 1987.

Mbanefoh, G. F.: Military Presence and the Future of Nigerian Fiscal Federalism, Faculty Lecture Series No. 1, Faculty of the Social Sciences, University of Ibadan, 1986(a).

- "Purchasing Votes and the Politics of Vertical Revenue Sharing: Debate Among Civilian Governments of the Second Republic of Nigeria", Administrative Change, Vol. XIV, Nos. 1-2, pp. 51-64,1986(b).

Okigbo, P. N. C: Nigerian Public Finance, London: Longmans, 1965. 